\title{
Applying Communicative Approach in Teaching English as a Foreign Language: a Case Study of Pakistan
}

\author{
SAEEd AhMAD \\ Institute of International \& Comparative Education, Northeast Normal University, China \\ Congman RaO \\ Faculty of Education, Northeast Normal University, China
}

Received: 20 June 2012 / Accepted: 14 February 2013

ISSN: $1697-7467$

\begin{abstract}
The first part of this research is comprised of an experimental study to investigate the comparative usefulness of the Grammar Translation Method and Communicative Language Teaching (CLT) approach in teaching English at the intermediate level. A pre-test, post-test group design was used to measure achievement and attitude of the students. The second part of this research is comprised of a survey study to investigate the Pakistani teachers' perception of the CLT approach and their perceived impediments in its application at the higher secondary level. A semi-structured questionnaire was used for this purpose, and ten teachers were interviewed.
\end{abstract}

Keywords: English in Pakistan, Communicative Approach.

Aplicación del enfoque comunicativo en la enseñanza del inglés como lengua extranjera: Un caso de estudio en Pakistán

RESUMEN: La primera parte de esta investigación consistió en un estudio experimental para investigar la utilidad comparativa del "método de traducción gramatical" y la enseñanza comunicativa de la lengua (CLT) aplicada al inglés de nivel intermedio. Se utilizó un diseño de pre-test, post-test para medir los logros y la actitud de los estudiantes. La segunda parte de esta investigación consistió en evaluar la percepción del método CLT y los impedimentos percibidos en su aplicación en la segunda etapa de educación secundaria mediante una encuesta. Para este propósito se utilizó un cuestionario semiestructurado; un total de 10 profesores fueron entrevistados.

Palabras Clave: Inglés en Pakistán, Enfoque comunicativo.

\section{INTRODUCTION}

Paradoxical, as it may seem, the English language runs like blood through the veins of nations worldwide. To have good communication skills in English is a burning desire for most people. Communicative competence in the target language is more demanded now than ever before.

The ever growing need for good communication skills in English has created a huge demand for English teaching around the world, as millions of people today 
want to improve their command of English or ensure that their children achieve a good command of English... The worldwide demand for English has created an enormous demand for quality language teaching and language teaching materials and resources (Richards, 2006: 05).

The worldwide increasing demand for good communication in the English language has increased significantly the responsibility of the English language teacher. The application of Communicative Language Teaching (CLT) has faced problems and resistance in the English as a Foreign Language (EFL) context (Ellis, 1996; Li, 1998; Liao, 2000). A positive relationship between communicative competence and language learning strategies has been reported. The purpose of the study was to evaluate implementation of a CLT approach in teaching English in Pakistani schools and colleges at a higher secondary level where the Grammar Translation Method (GTM) has been used for long. This situation is producing incompetent users of the English language in Pakistan.

This was a mixed method research, both qualitative and quantitative techniques were used to collect and analyze the data. A triangulation of data source was used to ensure the authenticity of findings. An experiment and survey studies were conducted, whereas two objectives guided this research: (1) to evaluate the feasibility of applying the CLT approach in Pakistan at intermediate levels of education. This objective was achieved through students' perspective by conducting an experimental study with 12th grade students for three months; whereas two groups of students were taught using the GTM and CLT approaches separately. The two groups' achievement and attitude in pre-test and post-test were compared; (2) to evaluate the teachers' perceptions about the theory and practice of the CLT approach and, the teachers' perceived difficulties in applying the CLT approach to teaching English at the higher secondary level in Pakistan. This objective was achieved by conducting a survey research with English language teachers at the higher secondary level in Pakistan. A structured questionnaire was used for this purpose. Besides this, ten teachers were selected amongst the questionnaire respondents for a semi-structured interview. The respondents identified four major kinds of difficulties, related to: (a) teachers, (b) students, (c) the education system in Pakistan and, (d) the theory and practice of CLT itself.

\subsection{Background of the study}

Pakistan is a multilingual country with almost 70 living languages. English, though not spoken as first language, is the primary secondary language to learn for education, business, traveling abroad or other needs. English is taught as a compulsory subject from grades one to twelve in Pakistan. The traditionally used GTM is not producing desired results, as the ever expanding domains of knowledge, globalization of the world, and an increasing use of the English language in all spheres of life demand the coming generation to become experts in the use of the English language, not only in its written form but also in its oral communication; it is used as a tool and means towards greater goals. English in Pakistan should be taught from an applied linguistics point of view (Jilani, 2004: 08). There should be a link in what the students learn in the classroom and in their real life situations.

English is considered as a foreign language in Pakistan. However some misconceptions also prevail about its status as a foreign or second language. The proponents of the idea of 
English as a foreign language claim that though English is the language of business, court, military affairs, education etc., it is not a means of communication among the masses. Students rarely find any chance to use English outside the classroom. Hence, English has a foreign language context in Pakistan. The difference of English as a Second Language (ESL) and EFL is one of the major challenges in adopting the CLT approach in a non-native environment. The practitioners are trying their best to implement this methodology equally well in both contexts, nevertheless its application in an EFL context is still under high criticism from different corners. Both of these contexts have learners whose first language is not English, yet teaching is distinct in both cases. The difference of these two contexts has been distinguished well by Ellis (1996: 216) in the following words:

ESL is integrative, in that it is designed to help individuals function in the community, EFL is a part of the school curriculum, and therefore subject to contextual factors such as support from principal and the local community, government policy etc. It is also dependent on the teacher's language proficiency, teaching resource and, the availability of suitable material.

CLT approach is now being applied in many non-native countries where English has a foreign language (FL) orientation. For a clear understanding of the situation of English Language Teaching (ELT) in an EFL context, we should take a cursory look at some of the countries where it is being implemented. The purpose of this look is to see similarities and dissimilarities of the issues related to its implementation which have their origin in the varying socio-economic and cultural conditions. A review of the related literature can be helpful in drawing conclusions.

\section{Literature REVIEW}

With the advent of globalization, the 'ideal native speaker' idea has been on rapid decline. English language is supposed to serve the purpose of non-native English speakers who now outnumber native speakers. Since its inception, the proponents of CLT have been blowing trumpets to prove its efficacy in ELT. Although the matter is mostly in favor of applying the CLT approach in an EFL classroom, some criticism has been laid against it, which is, for the most part, justified when we evaluate its implementation in such countries as Korea, China, Japan, Bangladesh and Vietnam where EFL teaching faced a lot of hurdles caused by local conditions. Chowdhry (2010) wrote "when CLT was introduced, the English as a foreign language (EFL) context in which it would inevitably be applied was not considered". As Ramanathan (1999: 212) also asserted "the much professed and popular theories (i.e. CLT) devised in the inner-circle of countries may or may not be compatible with the teaching conditions in the outer-circle countries". This highly westernized methodology of ELT was alien to the locally sanctioned teacher-centered system where the authority of the teacher has local and cultural approval. Although teaching should never be stagnant, a paradigmatic shift in teaching methodology can cause a total collapse in language teaching. ESL/ EFL necessarily takes a cross-national and multi-cultural aspect, which has to consider local needs and socio-economic conditions. Researchers and other stakeholders are keen to know its efficacy in Southeast Asian countries. Writing in a Chinese context, Wei (2011) wrote 
Given the gap between the theories of communicative competence and the task confronting EFL teaching and learning, most of the previous research studies maintained that EFL countries should carefully study their English teaching situations and decide how CLT can best serve their needs and interests.

A study conducted in Vietnam identified class size, grammar-based examinations, and the instructors' lack of exposure to authentic language as constraints on using CLT. Another study on English teachers' perceived difficulties in adopting CLT in South Korea suggested that EFL countries like South Korea need to change their fundamental approach to education before CLT can be adopted, because the predominance of text-centered and grammar-centered practices in Korea does not provide a basis for the student-centered, fluency-focused, and problem-solving activities required by CLT ( $\mathrm{Li}, 1998: 66$, as mentioned in Wei, 2011). Vasilopoulos (2008) writes that

Many years have passed since the introduction of CLT approach in Korea, however despite curriculum reform and passage of time, many remain skeptical of the effectiveness of communicative methodology in the Korean English language class room.

In China too, where the call for adoption of CLT was not accidental, it came from the educational problem that needed to be solved. This problem was the existing unsatisfactory teaching results of the traditional grammar-oriented method (Liao, 2000). The introduction of the CLT approach faced many hurdles in the Chinese context, as Liao quotes Hird (1995) saying that

The teachers believed that it was not feasible to adopt CLT because China had its special characteristics. These characteristics included the teachers' inability to teach communicatively and grammar-focused examination pressure...And may be that is just as well because China is a vastly different English language teaching environment from the one that spawned and nurtured the communicative approach.

The government's educational policies and a special focus on increasing the students' communicative competence paved the way for the CLT approach in China. Wenjie (2009) refers to Guangwei $\mathrm{Hu}$ (2005: 637) who says that

Despite a lack of consensus among researchers regarding the appropriateness of CLT for China, the Ministry of Education was impressed by the high profile that the methodology enjoyed internationally and was convinced that it would provide the best solution for the wide spread problem of students' low competence in using English for communication even after years of formal instruction in the language.

Akram \& Mehmood (2011: 175) report an experimental study conducted to know the importance of introducing the communicative approach in ELT in teacher training programs in Pakistan. They write 
CLT enhances the learners' confidence and it gives a sense of satisfaction to the teacher as well in the sense that s/he is successful in making the students use the foreign language in their conversation. CLT gives clarity to the expression... communicative approach is better than all the other methods of language teaching in general and Grammar Translation Method (GTM) in particular because the GTM is more concerned with teaching about language rather than language itself whereas communicative approach establishes a direct bond between the experience and the expression.

The review of related literature on CLT provides ample proof of its usefulness in English language teaching, despite the fact that some problems still persist. Here, a need arises to evaluate the feasibility of applying a communicative approach in those non-native countries where traditional methodology is still being used in ELT.

\section{RESEARCH METHODOLOGY}

This research comprised of two parts addressing the two research objectives, i.e., the feasibility of applying the CLT approach from students' perspective, and teachers' perceptions of the CLT approach and their perceived difficulties in its application. The two parts are detailed below

\subsection{Research objective one: The feasibility of applying the CLT approach in Pakis- $\tan$}

This objective aimed to investigate the appropriateness of applying the communicative approach in teaching English at Higher Secondary level. The study was based on the Watanabe, et al (1984) model. It was experimental in its kind and a pre-test/post-test equivalent group design was selected for this purpose. The achievement of two groups in pre-test and post-test was measured and compared with each other. Besides this, attitude of the students in the two groups before treatment and after treatment was measured and compared to find any significant difference as a result of treatment.

\subsubsection{Sample population}

The sample population consisted of forty male students in the 12th grade of a local college in (Punjab) Pakistan. A class with forty students was chosen for the experiment. The class was further divided into two equal groups with twenty students each, Control Group (CG) and Experimental Group (EG).

\subsubsection{Research instrument}

For treatment purposes, prescribed syllabus for students at the intermediate level was used, and the study was a continuum of the students' curricular activities with a purpose of not wasting their time for preparation of their final examination. In the pre-test and post- 
test, the students were tested for comprehension (10 marks), vocabulary (05 marks), use of idioms and phrases (10 marks), essay writing (15 marks); and speaking (20 marks). The speaking part of the test was comprised of two portions: part A (10 marks) dealing with their achievement in group discussions on general topics related to daily life situations; and the part B (10 marks) dealing with their understanding and communicative ability in context (syllabus). The total marks allotted in the writing portion were 40 and the speaking tests were 20. For measuring the attitude of two groups, a Likert scale with 26 items was prepared, and the same scale was used in pre-and-post treatment tests of attitude. The 26 items on the Likert scale were divided in seven positive and 19 negative statements; and every statement comprised of five options with Strongly Agree(SA), Agree (A), Neutral (N), Disagree (D) and, Strongly Disagree (SD). The distribution of credit on attitude was 5, 4, 3, 2, 1 in the case of a positive statement, and vice-versa for a negative statement. The maximum score on the attitude scale was 130 and the minimum score was 26 .

\subsubsection{Conducting research}

CG and EG were taught separately by two teachers who used the traditional (GTM) method and the Communicative (CLT) method respectively for a period of three months. A teacher-made pre-test was used to evaluate the proficiency levels of the two groups in the subject of English. A teacher-made post-test, same in difficulty level with that of the pre-test, was conducted to measure the achievement of two groups. The purpose was to examine the difference, if any, in the achievement of both groups taught with different methodologies. During the treatment period, the two groups were taught chapter 1 through 10 from the novel 'Goodbye Mr. Chips' as included in their syllabus, the use of idioms and phrases, and essay writing. The attitude of sample students (CG \& EG) towards learning the English language was measured twice: before the treatment period, and after the treatment period. The purpose was to see relative improvement in attitude, if any, as a result of treatment.

\subsubsection{Validity and reliability}

The validity of pre-test and post-test was ensured by matching items, their gravity and difficulty level with the previous Examination Board's question papers, and critical judgment by two expert English teachers at the intermediate level. The reliability of pre-test and posttest on Cronbach's Alpha was 0.79 . The validity of attitude scale construction was ensured by getting expert opinions of two professors and administering this attitude scale on 20 students $(10+10)$ not included in the experimental study, known for their positive and negative attitudes about learning the English language. The average score for positive attitude was measured at 98 and, negative attitude at 48 in pilot testing. The same procedure with a gap of two weeks (test-retest technique) was adopted to ensure the reliability of attitude scale. Reliability of CG and EG attitude in pre-test and post-test on Cronbach's Alpha was 0.87.

\subsubsection{Results (Experimental Study)}

The data obtained from achievement test (pre-test and post-test) of CG and EG was tabulated and interpreted using Mean, Standard Deviation (SD) and T test. In pre-test, the 
mean score of CG and EG was 21.50 and 20.85, respectively. The difference between the two mean scores was 0.70 , which was greater than 0.05 level alpha. So, no significant statistical difference was found between the two means obtained by CG and EG. This finding signifies that the two groups were almost equal in English language achievement before the treatment period (Table 1). In the post-test, mean scores obtained by CG and EG were 23.15 and 26.45 respectively. The difference between the two mean scores was 0.002 which was less than 0.05 level alpha. So, significant statistical difference was found between the two means which indicates that EG outscored CG in achievement after the treatment of three months (Table 1).

Table 1: Overall achievement in pre-test and post-test by $C G$ and $E G$.

\begin{tabular}{|l|c|c|c|c|c|c|c|}
\hline Segments & Group & $\mathbf{n}$ & $\mathbf{M}$ & S.D & SE(D) & T Value & Sig. \\
\cline { 1 - 7 } Pre-test & CG & 20 & 21.50 & 5.35 & 1.65 & .39 & .696 \\
\cline { 2 - 5 } & EG & 20 & 20.85 & 5.09 & & & \\
\hline Post-test & CG & 20 & 23.15 & 3.10 & .97 & -3.4 & $\mathbf{0 0 2}$ \\
\cline { 2 - 5 } & EG & 20 & 26.45 & 3.03 & & & \\
\hline
\end{tabular}

A detailed segmental pre-test result also indicates that the two groups were almost equal in English proficiency and there was no statistically significant difference found between the achievements of the two groups in any part of the achievement test, while the standard of significance was 0.05 at alpha (Table 2).

Table 2. Detailed achievement in pre-test by two groups.

\begin{tabular}{|c|c|c|c|c|c|c|c|}
\hline Parts of test & Group & $\mathbf{N}$ & $\mathbf{M}$ & S.D & SE(D) & t Value & Sig. \\
\hline \multirow[t]{2}{*}{ Comprehension } & $\mathrm{CG}$ & 20 & 4.50 & .95 & \multirow[t]{2}{*}{.33} & \multirow[t]{2}{*}{.92} & \multirow[t]{2}{*}{.362} \\
\hline & EG & 20 & 4.20 & 1.10 & & & \\
\hline \multirow[t]{2}{*}{ Vocabulary } & $\mathrm{CG}$ & 20 & 2.45 & 1.00 & \multirow[t]{2}{*}{.34} & \multirow[t]{2}{*}{.73} & \multirow[t]{2}{*}{.468} \\
\hline & EG & 20 & 2.20 & 1.15 & & & \\
\hline \multirow[t]{2}{*}{ Idioms } & $\mathrm{CG}$ & 20 & 3.20 & 1.47 & \multirow[t]{2}{*}{.47} & \multirow[t]{2}{*}{-.21} & \multirow[t]{2}{*}{.832} \\
\hline & EG & 20 & 3.30 & 1.49 & & & \\
\hline \multirow[t]{2}{*}{ Essay writing } & $\mathrm{CG}$ & 20 & 5.65 & 2.21 & \multirow[t]{2}{*}{.67} & \multirow[t]{2}{*}{-.07} & \multirow[t]{2}{*}{.941} \\
\hline & EG & 20 & 5.70 & 2.00 & & & \\
\hline \multirow[t]{2}{*}{ Speaking General } & $\mathrm{CG}$ & 20 & 2.80 & .70 & \multirow[t]{2}{*}{.21} & \multirow[t]{2}{*}{.00} & \multirow[t]{2}{*}{1.000} \\
\hline & EG & 20 & 2.80 & .61 & & & \\
\hline \multirow{2}{*}{$\begin{array}{l}\text { Speaking } \\
\text { Contextual }\end{array}$} & $\mathrm{CG}$ & 20 & 2.90 & .64 & \multirow[t]{2}{*}{.24} & \multirow[t]{2}{*}{.63} & \multirow[t]{2}{*}{.533} \\
\hline & EG & 20 & 2.75 & .85 & & & \\
\hline
\end{tabular}


Although the total score obtained by the two groups in the post-test signifies a statistically significant difference in achievement, yet the detailed result is partially inconsistent with the total result, which does not mar the authenticity of findings. In the segments of comprehension, vocabulary and essay writing, there was no significant statistical difference between the achievements of the two groups. While in the segments of idioms, speaking (general) test, and speaking (contextual) test, the difference between the achievements by the two groups was significant (Table 3).

Table 3: Detailed achievement in Post-test

\begin{tabular}{|c|c|c|c|c|c|c|c|}
\hline Parts of test & Group & $\mathbf{N}$ & $\mathbf{M}$ & S.D & SE(D) & t Value & Sig. \\
\hline \multirow[t]{2}{*}{ Comprehension } & $\mathrm{CG}$ & 20 & 4.75 & .79 & \multirow[t]{2}{*}{.28} & \multirow[t]{2}{*}{-.70} & \multirow[t]{2}{*}{.486} \\
\hline & EG & 20 & 4.95 & 1.00 & & & \\
\hline \multirow[t]{2}{*}{ Vocabulary } & $\mathrm{CG}$ & 20 & 2.55 & .76 & \multirow[t]{2}{*}{.22} & \multirow[t]{2}{*}{.46} & \multirow[t]{2}{*}{.648} \\
\hline & EG & 20 & 2.45 & .60 & & & \\
\hline \multirow[t]{2}{*}{ Idioms } & $\mathrm{CG}$ & 20 & 3.00 & 1.21 & \multirow[t]{2}{*}{.34} & \multirow[t]{2}{*}{-3.81} & \multirow[t]{2}{*}{.001} \\
\hline & EG & 20 & 4.30 & .92 & & & \\
\hline \multirow[t]{2}{*}{ Essay writing } & $\mathrm{CG}$ & 20 & 5.90 & .97 & \multirow[t]{2}{*}{.39} & \multirow[t]{2}{*}{-1.17} & \multirow[t]{2}{*}{.250} \\
\hline & EG & 20 & 6.35 & 1.42 & & & \\
\hline \multirow[t]{2}{*}{ Speaking General } & CG & 20 & 3.45 & .69 & \multirow[t]{2}{*}{.21} & \multirow[t]{2}{*}{-4.00} & \multirow[t]{2}{*}{.000} \\
\hline & EG & 20 & 4.30 & .66 & & & \\
\hline \multirow{2}{*}{$\begin{array}{l}\text { Speaking } \\
\text { Contextual }\end{array}$} & $\mathrm{CG}$ & 20 & 3.55 & .69 & \multirow[t]{2}{*}{.20} & \multirow[t]{2}{*}{-4.40} & \multirow[t]{2}{*}{.000} \\
\hline & EG & 20 & 4.45 & .60 & & & \\
\hline
\end{tabular}

The study showed that, if provided with suitable conditions, a better classroom environment with audio/visual aids like computer, multimedia, OHP, etc., a well-trained and active teacher with a good command of English using communicative approach to facilitate his/her purpose of teaching can produce better results than teaching through traditional methods. It proves the fact that the CLT approach is more suitable for teaching English as a foreign language than the traditional method (GTM). A partial inconsistency in the segmental result may be due to the limited treatment period. EG significantly improved in speaking skill. It proves that using the CLT method improves communicative skills of the learners.

The below table shows the mean attitude score obtained by CG and EG calculated through a Likert scale with five points. In the pre-test attitude, CG achieved 96.75 and EG 95.25, and the difference between two mean scores was 0.72 which was statistically not significant at .05 alpha. This indicates that both the groups possessed almost the same attitude towards learning English language before the treatment period. However, the mean attitude score after the treatment period was 96.95 and 104.65 by CG and EG, respectively, and the difference between the two mean scores was 0.026 which was statistically significant at 0.05 alpha (Table 4). 
Table 4: Attitude score by $C G$ and EG in Pre-test and Post-test

\begin{tabular}{|l|c|c|c|c|c|c|c|}
\hline Segments & Group & N & M & S.D & SE(D) & $\begin{array}{c}\text { T } \\
\text { Value }\end{array}$ & Sig. \\
\cline { 1 - 7 } Pre-test & CG & 20 & 96.75 & 15.85 & 4.08 & .37 & .715 \\
\cline { 2 - 7 } & EG & 20 & 95.25 & 9.05 & & & \\
\hline \multirow{2}{*}{ Post-test } & CG & 20 & 96.95 & 13.56 & \multirow{2}{*}{3.32} & -2.32 & $\mathbf{. 0 2 6}$ \\
\cline { 2 - 5 } & EG & 20 & 104.65 & 6.06 & & & \\
\hline
\end{tabular}

This result of attitude testing indicates that students' motivation for learning increases with applying the CLT approach. The attitude of EG was seen to change positively towards learning English by using innovative techniques during the treatment period.

\subsection{Research objective two: Teachers' perceptions of the CLT approach and their perceived difficulties in its application}

This research objective was further categorized into two parts:

- Teachers' perceptions about the theory and practice of the CLT approach

- Teachers' perceived difficulties in implementing the CLT approach in Pakistan

To achieve this objective, two research methodologies were adopted: (a) a survey study, and (b) an interview with teachers. The two methodologies are further elaborated below.

\subsubsection{Survey study}

The sample population was comprised of 150 English language teachers, teaching at the intermediate/higher secondary level of the Multan district, Punjab (Pakistan), out of which there were 128 respondents. One specific district of the province of Punjab was selected purposively. The sample population was both urban and rural; male and female; and from public and private schools and colleges. The participants were given the questionnaires personally, and they were given enough time to complete and return them to the researcher. A semi-structured questionnaire with two parts was developed for the survey study. The first part of the questionnaire related to demographic information (Table 5). The second part of questionnaire comprised on a Likert scale and each item had five options, i.e. Strongly Agree (SA), Agree (A), Neutral (N), Disagree (D), and Strongly Disagree (SD). The statements in the Likert scale dealt with the teachers' understanding of the use of the CLT approach in teaching English and their perceived difficulties in its application in a Pakistani context (Table 7-11). 
Table 5. Demographic information of the participants.

\begin{tabular}{|l|c|c|c|}
\hline & & Frequency & Percentage \\
\hline Gender & Male & 73 & $57 \%$ \\
\hline Urban/Rural & Female & 55 & $43 \%$ \\
\hline & Urban & 102 & $80 \%$ \\
\hline Organizational Setup & Rural & 26 & $20 \%$ \\
\hline & Public & 92 & $72 \%$ \\
\hline Qualification & Private & 36 & $28 \%$ \\
\hline & MA/M.Sc. & 117 & $91 \%$ \\
\hline
\end{tabular}

\subsubsection{Interview}

The interview was a continuum of the survey research. The purpose of interview was to fill in the gaps, if any, in information collected through the questionnaire. Ten teachers among the 128 respondents of the questionnaire were contacted for interviews. Their selection was made on the basis of their responses to certain items in the questionnaire, like the matter of selecting teaching methodology. For the purpose of observing research ethics, the names of participants were kept anonymous. Hence the ten participant identifiers were pseudonyms such as P1, P2...P10 (Table 6).

Table 6. Demographic information of the interviewees.

\begin{tabular}{|c|c|c|c|c|c|c|c|}
\hline $\begin{array}{l}\text { Sr. } \\
\text { No }\end{array}$ & Gender & $\begin{array}{l}\text { Urban/ } \\
\text { Rural }\end{array}$ & $\begin{array}{l}\text { Affiliation } \\
\text { (Public/ } \\
\text { Private) }\end{array}$ & $\begin{array}{l}\text { Academic } \\
\text { Qualification }\end{array}$ & $\begin{array}{l}\text { Professional } \\
\text { Qualification }\end{array}$ & $\begin{array}{l}\text { Teaching } \\
\text { Experience }\end{array}$ & $\begin{array}{l}\text { Experience } \\
\text { of teaching } \\
\text { abroad }\end{array}$ \\
\hline P1 & Male & Urban & Public & M.A & B.Ed & 20 years & -- \\
\hline P2 & Male & Urban & Public & M.Phil & -- & 10 years & -- \\
\hline P3 & Male & Urban & Private & M.A & B.Ed & 18 years & -- \\
\hline P4 & Female & Urban & Private & M.A & B.Ed & 08 years & Yes \\
\hline P5 & Male & Rural & Public & M Phil & B.Ed & 22 years & Yes \\
\hline P6 & Female & Urban & Public & M.A & M.Ed & 30 years & -- \\
\hline P7 & Male & Urban & Public & M.A & B.Ed & 15 years & Yes \\
\hline P8 & Male & Urban & Public & M.Phil & B.Ed & 16 years & -- \\
\hline P9 & Male & Urban & Private & M.Phil & M.Ed & 10 years & Yes \\
\hline P10 & Male & Rural & Private & M.A & -- & 06 years & -- \\
\hline
\end{tabular}


The average length of an interview was 40 minutes. The interviewees were given options to respond to interview questions either in English or Urdu (their native language). However, interviewees mostly responded in English. These interviews were audio recorded and were transcribed the same day of their recording.

The data collected through interviews was analyzed thematically. Ezzy $(2002: 93,94)$ said "(In) disassembling and reassembling the data... codes do not emerge uninfluenced from the pre-existing theory". Hence the data were separated according to themes related to the research objectives.

\subsubsection{Results (Survey Study and Interview)}

The data obtained through the questionnaire was analyzed using a percentage for every item. As the interview was a continuum of the survey study, data achieved through interview was thematically presented with that of the survey study. The themes covered under this study were:

(i) Teachers perceptions of the theory and practice of the CLT approach

(ii) Teachers' perceived difficulties in applying the CLT approach in the area of (a) Teachers, (b) Students, (c) The education system of Pakistan, and (d) The theory and practice of the CLT approach.

\section{Teachers' perceptions of the theory and practice of the CLT approach}

The table below shows a clear understanding of the participants regarding theory and practice of the CLT approach. The majority agreed that CLT is a learner-centered approach. Item No. 2 asked whether CLT focuses only on speaking skill, but it is not true as CLT focuses on all the four skills. Item No. 3 relates to the fact of whether grammar is taught in the CLT approach. The response to this item is not very clear. It shows that teachers have mixed thoughts about this issue.

Table 7. Teachers' perceptions of the theory and practice of the CLT Approach.

\begin{tabular}{|l|l|c|c|c|c|c|}
\hline No. & \multicolumn{1}{|c|}{ Items } & SA & A & N & D & SD \\
\hline 1 & $\begin{array}{l}\text { CLT is learner centered } \\
\text { Approach }\end{array}$ & $25.00 \%$ & $63.28 \%$ & $7.03 \%$ & $4.68 \%$ & $0.00 \%$ \\
\hline 2 & CLT focuses only on speaking. & $1.60 \%$ & $10.90 \%$ & $18.80 \%$ & $49.20 \%$ & $19.50 \%$ \\
\hline 3 & CLT does not teach grammar. & $8.59 \%$ & $26.56 \%$ & $28.12 \%$ & $28.90 \%$ & $7.81 \%$ \\
\hline 4 & $\begin{array}{l}\text { CLT gives less importance to } \\
\text { reading and writing. }\end{array}$ & $7.81 \%$ & $44.53 \%$ & $17.96 \%$ & $24.21 \%$ & $5.46 \%$ \\
\hline 5 & $\begin{array}{l}\text { CLT involves teaching of } \\
\text { culture of target language. }\end{array}$ & $9.37 \%$ & $14.84 \%$ & $26.56 \%$ & $35.93 \%$ & $13.28 \%$ \\
\hline 6 & $\begin{array}{l}\text { CLT demands using only } \\
\text { English in the class room. }\end{array}$ & $43.80 \%$ & $47.70 \%$ & $5.50 \%$ & $3.10 \%$ & $0.00 \%$ \\
\hline
\end{tabular}


(Interview) All ten interviewees were found unanimous on one issue CLT is a learnercentered approach. However, they differed slightly to the extent to which students should be given authority of their learning in the classroom. Some interviewees expressed their apprehensions on the students going astray during the process of learning. Their argument was based on the cultural tradition in Asian classrooms where the teacher has long been regarded as a master, next to a father figure in levels of respect. If the system is changed into a total student-centered classroom, some students may feel a dearth in teachers' patronage. On the issue of putting emphasis on four language skills, the participants differed. P1 and P7 emphasized improving listening and speaking skills of the learners. They based their argument on the fact that our students start learning English as a compulsory subject from grade one; and they possess enough knowledge of language. The 12th grade is the stage where they should be provided extensive listening and speaking practices. P3, P5, P8 and P10 advocated a balanced emphasis on all the language skills. They referred to the IELTS examination which covers testing of four language skills. The matter of teaching grammar in communicative approach was a controversial one. Some commented that teaching grammar is not a characteristic of the CLT approach. Hence it should not be included in class room instruction. However, the majority favored an integrative instruction model where grammar should be taught inductively. Regarding whether the culture of the target language should be included in instruction, the interviewees expressed different views. P10 commented that:

\begin{abstract}
We cannot implement CLT in letter and spirit until we also teach the traditional values of the people of the language; their manners of addressing each other, expression on dressing and eating, their values and the matters of heart and spirit, flesh and blood etc., all need to be taught to the learners for full understanding of the system how language works in original context.
\end{abstract}

The participants mostly favored the use of only English language in the class room. However, P2 referenced some linguists who claim that language is best learnt with comparing and contrasting the target language with that of L1. But the others agreed that for the matter of fluency in the target language, the use of the mother language or any other local language should be avoided.

\title{
Barriers in implementing the CLT Approach in Pakistan
}

The following part relates to the teachers' perceived difficulties in implementing the CLT approach in a Pakistani context. For convenience, this part has further been divided into four categories:

(a) Teachers' related issues: Teachers' lack of proficiency in English, work load and their understanding of the implementation of the CLT approach were included in this part. The result of the three items is evident. These items are a genuine concern of the teachers in implementing the CLT approach 
Table 8. Problems related to teachers.

\begin{tabular}{|l|l|c|c|c|c|c|}
\hline No. & \multicolumn{1}{|c|}{ Items } & SA & A & N & D & SD \\
\hline 1 & $\begin{array}{l}\text { CLT requires high proficiency of the } \\
\text { teacher }\end{array}$ & $47.65 \%$ & $35.93 \%$ & $5.46 \%$ & $10.15 \%$ & $0.78 \%$ \\
\hline 2 & $\begin{array}{l}\text { Teachers' have low resources and less } \\
\text { time for material preparation }\end{array}$ & $15.62 \%$ & $44.53 \%$ & $10.15 \%$ & $24.21 \%$ & $5.46 \%$ \\
\hline 3 & $\begin{array}{l}\text { Teachers lack training and full } \\
\text { understanding of CLT approach }\end{array}$ & $20.46 \%$ & $24.06 \%$ & $16.40 \%$ & $18.59 \%$ & $19.46 \%$ \\
\hline
\end{tabular}

(Interview) Almost all the interviewees unanimously emphasized the role of teacher in applying the communicative approach in the classroom. Teachers' proficiency in the use of the target language is a must. There was a general argument about the lack of teachers' training programs in Pakistan. P5 and P8 commented on the sluggish role played by the education department in providing refresher courses on a regular basis. P4 said that

You know that teaching is an ever evolving phenomenon. The rapid changes in course of study and shift of examination patterns require teachers training in the new system. I think that there should be held training workshops and refresher courses at least once in a year and the best suited time for it is the long summer vacations in Pakistan.

The respondents emphasized teacher training in using the communicative approach in the classroom. P7 said "only theoretical knowledge of any methodology is not enough. Most of the teachers know the theory of CLT. But how to use this methodology in creating real life situations in the classroom is important". The other major argument was the burden placed on teachers. Normally a teacher is required to teach more than four classes a day. More so, $\mathrm{s} /$ he has to teach various courses at different levels. For example if the institute is providing science, humanities and business courses, the English teacher is supposed to teach all the different courses to different groups of students. P1, P2 and P5 commented that teachers have no time to prepare class material. Most of the time, s/he has to rely on the text book which, according to some, makes teaching tedious and boring. P 9 said that

The teachers should be provided computers and they should have enough time to prepare their material for teaching. Then we can expect innovative and creative teaching in applying communicative approach.

(b) Student-related issues: Students' proficiency in English and their willingness and motivation for participation in classroom activities were the points discussed under this head. 
Table 9. Problems related to students.

\begin{tabular}{|l|l|l|l|l|l|l|}
\hline No. & Items & SA & A & N & D & SD \\
\hline 1 & $\begin{array}{l}\text { Students have low proficiency in } \\
\text { English. }\end{array}$ & $16.40 \%$ & $56.25 \%$ & $10.15 \%$ & $7.03 \%$ & $10.15 \%$ \\
\hline 2 & $\begin{array}{l}\text { Students are less confident and less } \\
\text { prepared for CLT. }\end{array}$ & $21.09 \%$ & $40.62 \%$ & $16.40 \%$ & $10.93 \%$ & $10.93 \%$ \\
\hline 3 & $\begin{array}{l}\text { Students resist in active participation in } \\
\text { communicative activities }\end{array}$ & $27.34 \%$ & $38.28 \%$ & $10.93 \%$ & $15.62 \%$ & $7.81 \%$ \\
\hline
\end{tabular}

(Interview) Students' willingness in applying communicative activities was regarded as important by the interviewees. P 8 said,

Students' motivation can bring good results in improving the situation. If they are motivated and willing to use the target language in classroom, it will create an environment of the use of language which will result in improved communicative competence of the learners and, will also help teacher motivation.

P9 and P10 stated that students' motivation for learning can change the classroom environment and, their motivation comes from different sources. Due to the pressure of examination results and different social issues, students are less motivated to learn the use of language. There was also another argument about the low proficiency of students in English. P 3 argued that "some students lack the knowledge of the structure of language. Though every year they pass the examination, yet their knowledge of English is still not enough and they hesitate in participating in classroom activities".

(c) The education System of Pakistan: The items in the table below addressed some core issues related to the educational system of Pakistan. Under this head, the examination system of Pakistan, provision of $\mathrm{A} / \mathrm{V}$ aids and, large class size were the main issues. Despite their perception of a grim picture of the situation, the teachers were appeared hopeful for the implementation of the CLT approach in Pakistan.

Table 10. Problems related to the education system of Pakistan.

\begin{tabular}{|l|l|l|l|l|l|l|}
\hline No. & Items & SA & A & N & D & SD \\
\hline 1 & $\begin{array}{l}\text { CLT is unsuitable for existing examination } \\
\text { system in Pakistan. }\end{array}$ & $20.20 \%$ & $49.60 \%$ & $17.80 \%$ & $4.70 \%$ & $7.00 \%$ \\
\hline 2 & $\begin{array}{l}\text { The existing syllabus is not suitable for } \\
\text { communicative activities. }\end{array}$ & $17.18 \%$ & $48.43 \%$ & $21.87 \%$ & $8.59 \%$ & $3.90 \%$ \\
\hline 3 & $\begin{array}{l}\text { Class rooms are not equipped with A/V } \\
\text { aids for CLT. }\end{array}$ & $20.31 \%$ & $60.93 \%$ & $14.06 \%$ & $4.68 \%$ & $0.00 \%$ \\
\hline 4 & Large class size is a hurdle for CLT. & $30.46 \%$ & $37.50 \%$ & $11.71 \%$ & $17.96 \%$ & $2.34 \%$ \\
\hline
\end{tabular}


(Interview) It was general argument by the interviewees that the current examination system does not support the use of the CLT approach. It is focused on writing skill and other language skills are not evaluated. P 1 said when the teachers know and the students know that only the result in written examination is the most important, they put their all efforts to improve it. As a result, real learning is hampered. Another argument was about the current syllabus of English classroom which is mostly based on westernized literary work. Most of the interviewees stated that for the implementation of the communicative approach, they need a syllabus based on applied linguistics. The respondents also showed their concern with the lack of computers and other technological devices in the class room. One other argument was about the overcrowded classrooms. P 9 said if I have to teach fifty students, how I can risk applying any other method except the traditional lecture method. The interviewees were found unanimous on this issue. P 2 and P 7 argued that in a communicative classroom 20 students can be engaged, which is at present a rare phenomenon in Pakistan.

(d) The theory and practice of the CLT approach: The westernized orientation of the CLT approach and its application in an ESL and EFL context were the major points discussed under this head. Another issue was the availability of specific materials for the application of the CLT approach.

Table 11. Problems related to the theory and practice of CLT itself.

\begin{tabular}{|l|l|c|c|c|c|c|}
\hline No. & \multicolumn{1}{|c|}{ Items } & SA & $\mathrm{A}$ & $\mathrm{N}$ & $\mathrm{D}$ & $\mathrm{SD}$ \\
\hline 1 & $\begin{array}{l}\text { CLT needs specific materials for } \\
\text { teaching. }\end{array}$ & $0.78 \%$ & $7.03 \%$ & $14.84 \%$ & $47.65 \%$ & $29.68 \%$ \\
\hline 2 & CLT is unsuitable for Asian countries. & $1.60 \%$ & $12.40 \%$ & $17.10 \%$ & $48.90 \%$ & $19.40 \%$ \\
\hline 3 & $\begin{array}{l}\text { CLT is more suitable in ESL context, } \\
\text { rather than EFL }\end{array}$ & $8.59 \%$ & $23.43 \%$ & $22.65 \%$ & $29.68 \%$ & $15.62 \%$ \\
\hline 4 & CLT lack assessment instruments & $31.30 \%$ & $27.50 \%$ & $13.80 \%$ & $18.40 \%$ & $09.00 \%$ \\
\hline
\end{tabular}

(Interview) Most of the interviewees were found convinced that communicative approach is applicable in EFL context. P6 argued we cannot ignore the role of CLT approach in improving communicative competence of the learners in other EFL countries. If it is applicable in other countries, it is applicable in our system too. P 8 commented

It is a false belief that our students have less chances of communication in target language out of the classroom. The majority of students have access to computers which can be used for this purpose. The need is to stimulate students towards this direction and the role of teachers is important in this respect.

Another argument was about the use of specific material for communicative activities in the classroom. Again the role of teacher was emphasized by the majority of interviewees. On the issue of using authentic material in classroom, P3 and P7 rejected the idea. They emphasized that the existing material and text books can be molded to create real life-like situation until a revised syllabus is provided. 


\section{Conclusion}

It can be concluded from the data of the two empirical studies discussed above that the communicative approach is better than the traditional method (GTM) in teaching English at the higher secondary level in Pakistan. The experimental study included in this research proved the fact that, if provided with suitable conditions, Pakistani learners can increase their communicative ability. The use of the CLT approach has shown to increase motivation for learning. The survey study also signifies the possibility of implementing the CLT approach in Pakistan. The respondent teachers showed their willingness to incorporate communicative activities in classrooms. They have a good understanding of the use of the CLT approach. The identified impediments in applying the communicative approach are teacher training, students' hesitation in the use of target language, over-crowded class rooms, grammar-based examinations, and the lack of appropriate materials. However, the teachers in this study were found to be enthusiastic to apply the communicative approach in the classroom. They appeared hopeful that the problems associated with the implementation of the CLT approach in Pakistan can be overcome.

\subsection{Discussion and suggestions}

Graduates with good communication skills are in a better position to explore new avenues in this highly economized society. Pakistani learners lack in English language communication skills, and the use of old traditional methodology is one, among other, causes for this shortcoming. Students take English as a compulsory subject from grades one through twelve, yet they cannot communicate well in English.

The conditions under which English is taught in Pakistan are not conducive to teaching and learning language...It is clear that the methods of teaching English language in Pakistan have not yielded the desired objective, i.e. communicative competence (Jilani, 2004: 01).

Communicative competence as a result of the CLT approach should be acknowledged. This research can prove to be a milestone in this direction. The education department and other stakeholders need to understand the importance of using the CLT approach for helping learners become well versed in English. The syllabus for English language teaching may be revised accordingly. Teachers' training programs should include the use of technology in teaching and a focus on increasing communication on the part of learners should be emphasized. Further research is needed to explore techniques in filling the gap between an ESL and EFL context to fully utilize the CLT approach. The examination system should not focus only on writing skills, and the evaluation of all language skills should be ensured. Teacher training programs should include the use of the CLT approach in ELT.

\subsection{Further research}

The implementation of the CLT approach is a harbinger of new era for non-native speaking countries, if the attainment of communicative competence in target language is the goal. 
Further research in this area should be conducted on a large scale. The application of the CLT approach should be tested on different levels of education, such as primary, elementary, secondary and higher education. All of the four language skills should be included in language assessment. Further work is also needed in syllabus design for the CLT approach.

\section{REFERENCES}

Akram, M. \& Mehmood, A. (2011). "The need of communicative approach (in ELT) in teacher training program in Pakistan", in Language in India, 11, 5: 172-178.

Chowdhry, M. R. (2010). "International TESOL training and EFL contexts", available from http:// alwaysingreen.blogspot.com/2010/12/International-tesol-training-and-efl.html accessed 08 July, 2011.

Ellis, G. (1996). "How culturally appropriate is the communicative approach?" in ELT Journal, 50, 3: 213-218.

Ezzy, D. (2002). Qualitative Analysis. Crows Next, NSW: Allen \& Unwin

Hu, G. (2005). "Contextual influences on instructional practices: a Chinese case for an ecological approach to ELT", in TESOL Quarterly, 39, 4: 635-660.

Hird, B. (1995). "How communicative can English language teaching be in China?", in Prospect, 10, 3/Australia.

Jilani, W. (2004 ). "Conditions under which English is taught in Pakistan : an applied linguistic perspective", in SARID Journal, 1, 1: 01-09.

Li, D. (1998). "It's always more difficult than you plan and imagine: teachers' perceived difficulties in introducing the communicative approach in South Korea", in TESOL Quarterly, 3, 4: 677-703.

Liao, X. Q. (2000). "How CLT became acceptable in secondary schools in China?", in The Internet TESOL Journal, available from http://iteslj.org/Articles/Liao-CLTinChina.html, accessed June 20. 2011

Ramanathan, V. (1999). "English is here to stay: a critical look at institutional and educational practices in India", in TESOL Quarterly, 33, 2: 211-231.

Richards, J. C. (2006). Communicative Language Teaching Today, New York: Cambridge University Press.

Vasilopoulos, G. (2008). "Adapting communicative language instruction in Korean universities", in The Internet TESOL Journal, 14, 8: August, 2008.

Watanabe, P., Hare, V. C. \& Lomax, R. G. (1984). "Predicting news story content from headlines, an instructional study", in Journal of Reading, 27, 5: 436-442.

Wei, L. (2011). "CLT in EFL context: not a universal medicine", in IDIOM, 41, 3: Fall 2011/ conversations.

Wenjie, C. (2009). "Using CLT to improve speaking ability of Chinese non-English major students", M.A.thesis, University of Wisconsin Platteville. Retrieved from http//minds.wisconsin.edu/ bitstream/handle accessed on 18 September, 2011. 